\title{
Recycling of radioactively contaminated scrap from the nuclear cycle and spin-off for other application
}

\author{
U. Quade* and W. Müller*
}

\begin{abstract}
In the 1980ies, Siempelkamp foundry in Krefeld, Germany, developed a process to melt medium and slightly radioactive metals from decommissioning and maintenance works in nuclear power plants. Since 1989, in the CARLA melting plant which is licensed according to the German radiation protection ordinance (StrlSchV), metals are being molten which, for the largest part, can be reused. Since 1998, in a second plant, the GERTA melting plant, metals with a content of mercury up to 1 weight \%, natural radioactivity up to $500 \mathrm{~Bq} / \mathrm{g}$ and other chemical contaminations are being molten and completely decontaminated, so that these metals can be reused in the steel cycle. The following text is describing the melting process, acceptance criteria for contaminated scrap and recycling paths for the produced ingots and slags.
\end{abstract}

Keywords $\quad$ Radioactively contaminated scrap. Decontamination by melting. NORM. Casks for radioactive transports.

\section{Reciclado de chatarra contaminada por radiación en el ciclo nuclear y su aprovechamiento para otra aplicación}

Resumen

La fundición Siempelkamp en Krefeld, Alemania, desarrolló, en los años 80, un proceso para fundir metales mediana y levemente radioactivos, procedentes de reparaciones o desmantelamiento de plantas nucleares. En la planta de fundición CARLA, que cumple los requisitos del decreto de protección contra radiaciones de la República Federal de Alemania, se funden metales desde 1989, de los cuales la mayor parte puede ser utilizada nuevamente. Desde 1998, en una segunda planta, fundición GERTA, se funden y descontaminan totalmente, metales de hasta un $1 \%$ de peso de mercurio, con una radioactividad natural de hasta $500 \mathrm{~Bq} / \mathrm{g}$ y con otros contaminantes químicos. De este modo los metales pueden ser nuevamente utilizados en el ciclo metálico. El texto adjunto describe el método para el fundido, los criterios para aceptar chatarra contaminada y las vías de utilización para los bloques de metal y escorias generadas en el proceso.

Palabras clave Chatarra con contaminación radioactiva. Descontaminación por fusión. Transportes radioactivos.

\section{INTRODUCTION}

At the site of Siempelkamp Giesserei in Krefeld, Germany, a foundry with an annual capacity of 60,000 t of cast iron, Siempelkamp Nukleartechnik $\mathrm{GmbH}$ operates two additional melting plants for recycling of contaminated scrap, each with a capacity of 2,000 t/a. The first plant - CARLA can handle slightly radioactive material from maintenance and decommissioning of nuclear power plants, and its spin off plant - GERTA - can handle NORM (naturally occurring radioactive material) and chemically contaminated scrap. Both plants vary in the kind of licensing and due to that, in the reuse of the products. The metal blocks produced by the CARLA-plant are allocated to different paths according to the remaining activity - free release, reuse in shieldings or casks for the nuclear cycle or final depository. Siempelkamp Nukleartechnik already has experience in cooperating with Siempelkamp foundry in producing casks and containers in terms of radiation protection and paths of radionuclides. Current research and development deals with an increase of the recycling quota for this type of casks concerning metallurgy and chemistry. It turned out that recycling within the nuclear

$\left({ }^{*}\right) \quad$ Siempelkamp Nukleartechnik GmbH, Siempelkampstrasse 45, 47803 Krefeld, Germany. 
industry reduces the collective dose as well as the number of individuals having to handle radioactively contaminated material ${ }^{[1-3]}$. The GERTA plant is operating according to the $1 \mathrm{mSv} / \mathrm{a}$ criterium for workers and public ${ }^{[4]}$ and the metal products are free of any activity and can be reused in the conventional steel cycle.

\section{CARLA PLANT}

\subsection{Process}

Core of the plant is a $3.2 \mathrm{t}$ medium frequency induction furnace, located in an inner housing of the CARLA plant. Primarily the furnace is being operated for melting steel scrap, but its replacement by a special crucible also allows to melt non-ferrous metal. The inner housing is the barrier to the cutting and sorting shop to prepare the melt charges. To avoid emissions of radionuclides, all related sources as there are the furnace, the cutting and sorting areas, are equipped with a highly efficient exhaust system linked with a redundant filter system. The filter system, consisting of cyclone, bag filter and HEPA-filter, has an efficiency of $99.997 \%$. Charging the furnace, slagging and pouring is handled by remote control from an operation desk outside the inner housing, which reduces radiation exposure of the workers. Material can be delivered in 2001 - drums which are charged on-line or in $20^{\circ}$-containers. Large components up to dimensions of the $20^{\prime}$-container, have to be cut to chargeable sizes. A 450 t-hydraulic shear and a chamber with plasma torch cutting are available tools for cutting components. The scrap drums and containers as well as the waste drums to be sent back to the customer can be stored in a hall of $3,000 \mathrm{~m}^{3}$ storage volume being located beside the cutting area. The successful safe operation of the plant over more than 15 years is ensured by a continuous radiation protection management during the whole process. Sampling, measurement and documentation of radioactive inventories from the input to the output are therefore routine jobs. Two gamma-spectroscopy detectors are in operation in the accredited laboratory to analyze the samples taken from melt, slag, filter dusts, etc. ${ }^{[5]}$.

\subsection{Licensing}

The CARLA plant is licensed by the German Radiation Protection Ordinance. Limits of the incoming scrap are defined as specific activity figures averaged over 2001 - drums or 20'. containers as follows:

- total activity $(\alpha, \beta, \gamma)$

$200 \mathrm{~Bq} / \mathrm{g}$

- C 14, H 3, Ni 63, Fe 55 $2,000 \mathrm{~Bq} / \mathrm{g}$

- fissible nuclides (U 233, U 235, Pu 239, Pu 241) $<15 \mathrm{~g} / 100 \mathrm{~kg}$ scrap

- NORM (Ra-226, U-238, Th-232)

$1,000 \mathrm{~Bq} / \mathrm{g}$

The mass limitation is $2,000 \mathrm{t} / \mathrm{y}$ which is achieved in a one-shift operation. Workers are classified as class $\mathrm{A}$ in relation to the German radiation protection ordinance.

\subsection{Experiences}

In the 20 years of development and operation, $18,000 \mathrm{t}$ of radioactively contaminated metals have been molten, the distribution of which is $15,500 \mathrm{t}$ for a primary melt and additional 2,500 $\mathrm{t}$ for a secondary melt to produce granules from ingots or to improve the decontamination by second melting. The distribution of molten metals is as follows: carbon steel $(76 \%)$, stainless steel $(14.5 \%)$ and non-ferrous metal (9.5\%). Path of outcoming ingots from CARLA are shown in figure 1. as follows:

The advantages of melting can be summarized

- Decontamination

The radionuclide distribution resulting from the melting process is listed in table I. High decontamination of the metal can be achieved for uranium, thorium, plutonium, cesium and strontium. Co-60 the main nuclide in reactor scrap- remains in the melt. Nevertheless, the residual radionuclides in the metal are

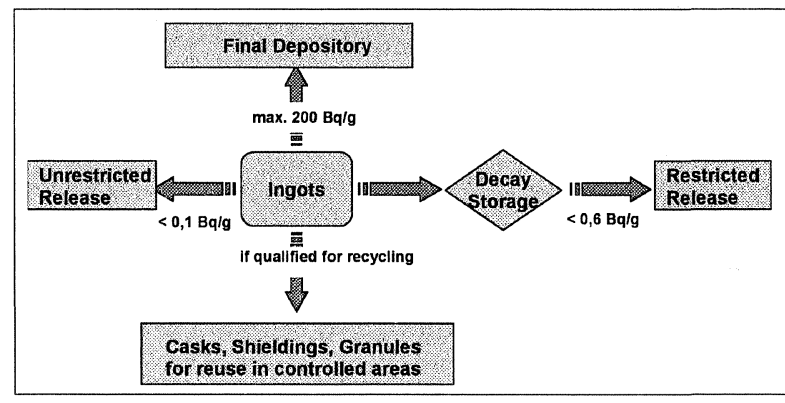

Figure 1. Paths of ingots with remaining Co-60 activity.

Figura 1. Recorrido de los lingotes con actividad Co-60, restante. 
Table I. Activity distribution after melting

Tabla I. Distribución de actividad, después de la fusión

\begin{tabular}{|c|c|c|c|c|}
\hline & \multirow[t]{2}{*}{ Nuclides } & \multicolumn{3}{|c|}{ Distribution in \% } \\
\hline & & Melt & Slag & Dust \\
\hline \multirow{5}{*}{$\begin{array}{l}\alpha \text {-Nuclides } \\
\text { (and daughters) }\end{array}$} & - U 235, U 238 & 1 & \multicolumn{2}{|c|}{99} \\
\hline & - Pu 241 & 1 & \multicolumn{2}{|c|}{99} \\
\hline & - Am 241 & 1 & \multicolumn{2}{|c|}{99} \\
\hline & - Th 231, Th 234 & 1 & \multicolumn{2}{|c|}{99} \\
\hline & - Pa 234m & 1 & \multicolumn{2}{|c|}{99} \\
\hline \multirow{15}{*}{$\beta / \gamma-$ Nuclides } & - Fe 55 & 100 & $<1$ & - \\
\hline & - Co 60 & 88 & 11 & 1 \\
\hline & - Ni 63 & 90 & 10 & - \\
\hline & - Sr 90 & $<1$ & 97 & 2 \\
\hline & - Cs 134, Cs 137 & $<1$ & 60 & 40 \\
\hline & $-\mathrm{Ag} 110 \mathrm{~m}$ & $<1$ & 32 & 68 \\
\hline & - Eu 152, Eu 154 & 4 & 95 & 1 \\
\hline & - Ce 144 & 50 & 50 & $<1$ \\
\hline & $-M n 54$ & 60 & 39 & 1 \\
\hline & - Zn 65 & 36 & 12 & 52 \\
\hline & - C 14 & - & 5 & 95 \\
\hline & - Zr 95 & 28 & 72 & - \\
\hline & - Ru 103, Ru 106 & 67 & $<1$ & 33 \\
\hline & - Sb 125 & 95 & 4 & 1 \\
\hline & - Nb 95, Nb 96 & 81 & 17 & 2 \\
\hline
\end{tabular}

homogenized and fixed into the ingot. The activity distribution after melting is shown in table I.

In most cases estimation of the specific activity in the supplied scrap can only be performed by methods which lead to overestimation. Samples are taken from the melt, the slag and the filter dust to analyze the activity inventories after the melting process. These figures are qualified and form the basis for managing the secondary waste and for recycling the metal.

- Volume reduction

A final depository for radioactive waste is very expensive throughout the whole world. Therefore, maximum volume reduction should be achieved, which can be realized by melting in an optimal manner. The experience of 20 years of melting and recycling of steel scrap results in saving a final depository volume of 80 $\%$ compared to direct disposal without any pretreatment.

\subsection{Recycling}

The different behaviour of the nuclides in the melting process and the different scrap qualities lead to different material qualities of the produced ingots. According to this fact different recycling paths have to be found.

- The prior possibility is an unrestricted or restricted release of the metal for conventional reuse in the steel cycle according to the German radiation protection ordinance (StrlSchV). For example Co-60: unrestricted release $0,1 \mathrm{~Bq} / \mathrm{g}$; restricted release $0,6 \mathrm{~Bq} / \mathrm{g}$. So far approximately $4,000 \mathrm{t}$ of metals could be released.

- In case these levels are exceeded a recycling path within Siempelkamp is possible according to StrlSchV. Siempelkamp produces different kinds of casks according to IAEA regulations for low and medium-level radioactive waste or shielding elements for the nuclear industry and research centres:

1. The "MOSAIK ${ }^{\circledR "}$ container is a cast iron container with a maximum of $25 \%$ recycling material from CARLA and a total weight of up to $6 \mathrm{t}$.

2. The "Cast Iron Container" meets the requirements for the German final depository "KONRAD" with a maximum of $25 \%$ recycling material and a total weight of $20 \mathrm{t}$.

3. The cast iron "shielding elements" contain recycling material of up to $90 \%$ and can be cast up to a weight of $150 \mathrm{t}$ per element. So far approximately 6,000 $\mathrm{t}$ could be recycled.

4. Apart from radiological reasons the stainless steel is not usable for cast products as described below. The stainless steel can be cast to granules. These granules are used for producing "heavy concrete containers" made of concrete and iron granules. These containers are licensed for transport and disposal and have a total weight of 2-14 t, depending upon their size. So far approximately $2,500 \mathrm{t}$ of granules could be recycled in heavy concrete containers.

5. As mentioned before, the main nuclide for low active nuclear waste is the Co-60, which has a short half life time of 5.3 years. For the future, Siempelkamp will offer an option to store ingots for a decay period of 20 years with the aim of release. 
- If there is no possibility to follow one of the above mentioned paths the ingots have to be stored in a final depository, however, with the advantage of a volume reduction of $80 \%$.

- Slag, dust and residues like furnace linings amount to about $5 \mathrm{wt}-\%$ of the total melting volume. According to StrlSchV this material can be released and disposed by conventional paths or has to be disposed as radioactive waste.

\subsection{Research and development in improving recycling quota for casks and containers}

The storage casks are made of cast iron and spheroidal graphite. After solidification of the melt from the high carbon content iron-silicon alloy, carbon is ideally available in the form of graphite particles being embedded in the metallic structure. Cast iron with spheroidal graphite has high strengths and strains. An other advantage of this material is its good shielding effect.

A standard size in container design is the fracture toughness of the material. In a special case of a container according to final depository requirements, e.g. stresses caused by accident from a height of $5 \mathrm{~m}$ with low material temperatures of $-20^{\circ}$ and $-40^{\circ}$ without crack initiation have to be controlled. The fracture toughness of the cast iron is primarily depending upon the structure of the metallic matrix. A ferritic structure owns a higher fracture toughness than a pearlite structure. Furthermore, carbide portions in the structure cause embrittlement. Metallic residues resulting from decommissioning of nuclear facilities, contain important rates of elements like $\mathrm{Mn}, \mathrm{Mo}, \mathrm{Cu}, \mathrm{Ni}$ and $\mathrm{Cr}$, which form pearlite and carbides in the cast structure already when added in small portions to the melt ( $<1 \%$ weight proportion each).With a rising rate of pearlite and carbide tensile strength and yield stress are increasing and elongation and fracture toughness are decreasing. In order to fulfill the requirement for sufficient fracture toughness, an upper limit of $20 \%$ for the embrittled structure parts of pearlite is applicable for the current container production. This limit can only be obtained by a limitation of kind and quantity of recycled metal scrap.

Within the Siempelkamp group research is performed with the aim to increase the recycling content in the containers. The focus here is the pearlitic microstructure and carbides caused by chromium, nickel and molybdenum in the recycled iron $^{[6 \text { and } 7]}$.

\section{GERTA}

Since 1998 Siempelkamp Nukleartechnik is operating a second melting plant at their site in Krefeld to treat radioactively, chemically (i.e. mercury) and toxically contaminated scrap. The GERTA facility is a spin-off of the CARLA facility and is licensed in accordance with the German BImSchG (Federal Law on protection against environmental pollution). GERTA facility is able to treat steel scrap contaminated with NORM from oil and gas extraction operations, fertilizer plants or paper mills. In some cases scrap, especially from oil and gas extraction operations, contains cross contaminations with mercury and NORM. Furthermore, mercury polluted steel scrap from chlorine production facilities throughout Europe and North America can be treated and additionally, steel scrap contaminated with PCB`s, furanes, dioxines or asbestos from different origins. Concerning the processing of NORM contaminated scrap the anual dose exposure to workers does not exceed $1 \mathrm{mSv}$ in the GERTA plant and therefore no licensing nor radiation surveillance or protection is required according to the StrlSchV ${ }^{[4]}$.

\subsection{Specification for incoming material}

The specification for incoming steel scrap originates from restrictions based on foundry processing and safety regulations:

- At present, the radiological acceptance limit is $500 \mathrm{~Bq} / \mathrm{g}$ total specific activity of NORM averaged over the whole steel mass.

- Mercury is limited to $1 \mathrm{wt}-\%$ of the steel mass.

- Asbestos is restricted to $0.1 \%$ of the steel mass.

\subsection{Process}

The GERTA process can be divided into three steps: dismantling, melting and off-gas processing.

\subsubsection{Melting}

All incoming material will be cut into chargeable sizes of $300 \mathrm{~mm} \times 300 \mathrm{~mm} \times 300 \mathrm{~mm}{ }^{[8]}$. The melting process in the $8 \mathrm{t}$-net-frequencyinduction-furnace has to be started with a 3 t sump of liquid iron followed by a batch of $5 \mathrm{t}$ of scrap. The furnace can be operated in the temperature range from $1,350^{\circ} \mathrm{C}$ up to $1,500^{\circ} \mathrm{C}$. The average 
melting time is $4 \mathrm{~h}$ which leads to a capacity of 30 $t$ per day in 3 -shift-operation. Additives as ferrosilica and carbon amount to $3 \mathrm{wt}-\%$ of the input. During the melting process, impurities of the different incoming materials behave in different ways ${ }^{[9-11]}$ :

- Hg: Elementary mercury evaporates completely and is fixed in the activated carbon. Partly it is absorbed by lime-powder which is added to the exhaust gas or by the dust.

- NORM: NORM behaves differently depending upon the kind of radionuclides. Radium isotopes are transferred into the slag which is gripped from the surface of the melt. Volatile isotopes like lead $(\mathrm{Pb}-210)$ and polonium (Po210) remain with the dust in the filter system (see table 2).

- Asbestos: The cancerogene asbestos fibres are destroyed completely at the above mentioned temperature level and are transformed into non toxic silicates as Forsterite or Olivine ${ }^{[12]}$.

\subsubsection{Off-gas-processing}

In case of any mercury evaporation in the dismantling or melting area, the air is filtered by two exhaust systems with a capacity of 15,000 $\mathrm{m}^{3} / \mathrm{h}$ each.

Dust and off-gas evaporate from the melt and pass through the exhaust cover to the filter plant, which consists of four steps, a cyclone, a cooler, a bag filter and a fixed-bed-absorber. This combination of filters prevents the mercury concentration in the chimney stack from exceeding $50 \mu \mathrm{g} / \mathrm{m}^{3}$, which is only $1 / 4$ of the permitted value. As NORM scrap is processed, vaporised $\mathrm{Pb}-210$ and $\mathrm{Po}-210$ condense and are absorbed by the dust and are retained in the bag filter. Asbestos fibres, PCB's, Dioxines and Furanes are not measurable in the clean gas, which is released to the environment. Dust emissions do not exceed $20 \mathrm{mg} / \mathrm{m}^{3}$ according to BImSchG.

\subsection{Products}

Products for recycling are metal (amounting to 90-95 wt-\%) and slag (4-10 wt-\%). Only the dust $(1-2 \mathrm{wt}-\%)$ has to be disposed underground. Iron and slag are free from any chemical or toxical contamination. The current product qualities are carbon steel, $\mathrm{Cr} / \mathrm{Ni}$ steel and alloys e.g. tungsten/molybdenum/iron.
The radionuclides migrate to slag or dust, so the melt is almost free from any radioactivity. The main nuclides of the uranium, radium and thorium decay chain remain in the slag (98\%), while lead and polonium evaporate and are collected with the dust $(93-98 \%)$.

\subsubsection{Slag}

The slag, with a maximum of $100 \mathrm{t} / \mathrm{y}$ in total, is free of toxic impurities and so far could be $100 \%$ processed to road construction material. In case of slag from NORM scrap campaigns, the radiation exposure of workers as well as of the public has to be less than $1 \mathrm{mSv} / \mathrm{y}^{[4]}$.

\subsubsection{Filter dust}

Only $1 \mathrm{wt} .-\%$ of the input-material is dust retained in the bag filter and in the cyclone. Both kinds of dust are mixed with quick lime and are then filled into storage drums. Up to one percent of mercury can be detected in the dust, blended with the lime, it is firmly bound. The activity of the drums must not exceed $70 \mathrm{~Bq} / \mathrm{g}$ to fulfill the criteria for underground depository.

\subsection{Current projects and research}

Research is currently conducted with:

- Thorium containing scrap from the lighting industry

- Thorium-tungsten containing residuals from welding electrodes

- Hg-contaminated glass waste to improve slag quality

\section{CONCLUSIONS}

Siempelkamp Nukleartechnik offers a service to decontaminate, condition and recycle slightly radioactive metal wastes from the nuclear cycle and as a spin-off the decontamination of radioactivity from natural sources and chemical contamination. Core of this service are two melting plants with a capacity of 2,000 t/y each, with the option of recycling the produced ingots in the conventional steel cycle or using them as raw material to manufacture containers for the nuclear industry. Meanwhile Siempelkamp has 20 years of experience in handling this kind of material and so far they could treat some $18,000 \mathrm{t}$ 
Recycling of radioactively contaminated scrap from the nuclear cycle and spin-off for other application U. QUADE AND W. MÜLleR

from the nuclear cycle and some 5,000 $t$ from the oil and gas and chemical industry.

\section{REFERENCES}

[1] R. GÖRTZ; R. GrAF and A.G. KNAUP, Strahlenexposition der Bevölkerung infolge der Freigabe von Eisenmetallschrott aus Kernkraftwerken zur schadlosen Verwertung, 1989, BMU. 1989-222, ISSN 0724 - 3316.

[2] R. GÖRTZ, R. GRAF and A.G. KNAUP, Untersuchung zur schadlosen Ver-wertung von Nichteisenmetallen, Ed. Bundesministerium für Umwelt, Naturschutz und Reaktorsicherheit, 1990, BMU - 1990 - 264, ISSN 0724 $-3316$.

[3] S. Kistinger, A. Deckert, R. Graf, R. Görtz, W. GOLDAMMER and S. THIERFELDT, Reaktorsicherheit und Strahlenschutz, BMU -1994 - 394.

[4] S. THIERFELDT and S. WÖRLEN, Radiologische Bewertung der Rückstände aus dem Schmelzprozess sowie Ermittlung von Annahmewerten für die GERTA-Anlage, Expert opinion, 2002.
[5] U. QUADE and S. KADEN, Recycling radioaktiver Reststoffe durch Schmelzen, atw 40. Jg, Heft 4.

[6] D. Bounin, W. Kleinkröger, U. Quade and D. SCHREIBER, Optimierung von Reststoffverwertung und Design von Lagerbehältern, KONTEC, Berlin, 2003.

[7] D. Bounin, U. Quade, D. Schreiber and W. Völzer, Optimized storage casks with increased content of recycled metals, Jahrestagung Kerntechnik, Stuttgart, 2002.

[8] M. BECK, Recycling International 2 (2002).

[9] M. HAMM and U. QUADE, Auslaufmodell Quecksilber, Chemie Produktion 11 (2000) 60-62.

[10] U. QuADE and M. HAMm, Chemie - Anlagen + Verfahren 5 (1998).

[11] M. HAMM, Recycling and disposal of byproducts and wastes originated from melting of NORM-scrap, Symposium NORM III, Brussels, 2001.

[12] K. Rosenbusch, Schadstoffe in baulichen und technischen Anlagen, Tagung des Fachverbandes Asbest Sanierung, Köln, 1993. 